\title{
SPILLOVER SPASIAL NEGATIF PERTUMBUHAN EKONOMI ANTAR KABUPATEN/KOTA DI PROVINSI JAWA TIMUR
}

\author{
Negative Spatial Spillover of Economic Growth Inter \\ Regencies/Cities in East Java Province
}

Hani Laksono ${ }^{1}$, Ernan Rustiadi ${ }^{1}$ and Hermanto Siregar ${ }^{2}$

Diterima: 18 November 2017

Disetujui: 11 Februari 2018

\begin{abstract}
Abstrak: Berbagai studi telah dilakukan untuk memahami faktor pertumbuhan ekonomi wilayah dan sifatnya dalam rangka mendapatkan formulasi kebijakan pembangunan wilayah yang tepat. Tujuan umum penelitian ini yaitu mengeksplorasi pengaruh spasial pertumbuhan ekonomi di wilayah Provinsi Jawa Timur. Hasil uji Lagrange Multiplier menunjukkan bahwa pertumbuhan ekonomi kabupaten/kota di saling mempengaruhi satu dengan yang lain dalam jangka panjang. Estimasi parameter pada spatial lag model menunjukkan bahwa pengaruh spasial pertumbuhan ekonomi antar kabupaten/kota tersebut bernilai negatif. Hal ini mengindikasikan bahwa kegiatan pembangunan di Provinsi Jawa Timur belum berjalan secara sinergis.
\end{abstract}

Kata kunci: Pertumbuhan Ekonomi Wilayah, Pengaruh Spasial, Spatial Lag Model

\begin{abstract}
Various studies have been conducted to conceive the factors of regional economic growth and its nature in order to obtain the right formulation of regional development policy. The main aim of this research is exploring the spatial influence of economic growth in East Java Province. The result of Lagrange Multiplier test shows that the regencies/cities economic growth affects each other in the long term. Parameters estimation on spatial lag model shows that the spatial influence of economic growth inter regencies/cities is negative. These indicate that development activities in East Java Province have not been get synergistic yet.
\end{abstract}

Keywords: regional economic growth, spatial influence, spatial lag model

\section{PENDAHULUAN}

Hakikat pembangunan wilayah, dalam perspektif ekonomi, secara sederhana dapat diartikan sebagai pertumbuhan ekonomi wilayah (Rustiadi et al. 2009). Berbagai studi dilakukan dalam rangka mengidentifikasi faktor-faktor utama yang menggerakkan pertumbuhan ekonomi (skala nasional maupun regional) dalam jangka panjang (Harris 2008). Pengetahuan mengenai faktor-faktor ini sangat penting sebagai landasan dalam perumusan kebijakan pertumbuhan ekonomi yang dilaksanakan oleh pembuat kebijakan (pemerintah).

\footnotetext{
${ }^{1}$ Program Studi Ilmu Perencanaan Pembangunan Wilayah dan Perdesaan, Institut Pertanian Bogor

${ }^{2}$ Departemen Ilmu Ekonomi, Institut Pertanian Bogor
} 
Dalam 50 tahun terakhir ini, model pertumbuhan ekonomi terus berkembang menawarkan berbagai pendekatan yang berbeda, dimulai dari model neoklasik yang dengan pendekatan supply-side, model basis ekspor dengan pendekatan demand-side, hingga pada pengembangan model neoklasik dengan pendekatan spasial (Harris 2008) serta munculnya pemikiran terhadap peran faktor intangible seperti modal manusia, modal sosial, kelembagaan, kepemimpinan, kerjasama antardaerah dan aspek spasial sebagai faktor endogen dalam proses pertumbuhan ekonomi (Harris 2008; Capello 2011; Capello \& Nijkamp 2011; Firman 2011; Rustiadi 2017). Perkembangan model pertumbuhan ekonomi ini menunjukkan bahwa fenomena pertumbuhan ekonomi merupakan suatu hal yang kompleks dan melibatkan banyak faktor baik tangible maupun intangible (Kenny \& Williams 2001).

Meskipun model neoklasik yang digagas oleh Solow pada 1956 dimana pertumbuhan supply dalam jangka panjang ditentukan oleh tingkat konsumsi, pertumbuhan modal, tenaga kerja dan kemajuan teknologi (Cheshire \& Malecki 2004; Blanchard 2007; Steindl \& Tichy 2009) telah mendapatkan berbagai kritik karena tidak mempertimbangkan eksistensi keterkaitan spasial antarwilayah (Cheshire \& Malecki 2004), namun model tersebut masih menjadi landasan dalam perumusan kebijakan dan program pembangunan di berbagai negara berkembang (Adisasmita 2008; Priyarsono 2016).

Eksistensi keterkaitan spasial antarwilayah dibuktikan oleh berbagai penelitian yang telah dilakukan dengan menggunakan metode pendekatan yang beragam, baik di bidang ekonomi (SAC et al. 2005; Suparta 2009; Junaidi et al. 2012; Veneri \& Ruiz 2013; Pribadi et al. 2014; Berdegue et al. 2015; Lehtonen et al. 2015; Pasaribu et al. 2015; Wardhana fet al. 2015; Arman et al. 2017) maupun di bidang non ekonomi (Pertiwi et al.2012; Maggioni et al. 2014; Pravitasari et al. 2016). Salah satu model pertumbuhan ekonomi wilayah yang terkenal dengan eksistensi keterkaitan spasialnya yaitu model kutub pertumbuhan yang digagas oleh Perroux. Perroux menjelaskan bahwa pertumbuhan yang terjadi pada kutub pertumbuhan akan menyebar melalui jalur tertentu dan mempengaruhi perekonomian secara keseluruhan melalui kekuatan-kekuatan sentrifugal keluar (spread effect/trickledown effect) dan sentripetal ke dalam (polarization effect/ spread effect) (Wojnicka 2014). Oleh karena itu, jika terdapat sebuah pernyataan mengenai pertumbuhan di sebuah kutub pertumbuhan, maka secara otomatis berkaitan dengan pembangunan di wilayah-wilayah belakangnya (hinterland) (Cheshire \& Malecki 2004).

Jika Perroux berhipotesis bahwa spread effect akan lebih besar daripada polarization effect sehingga pemerataan pertumbuhan ekonomi antarwilayah akan terwujud, sebaliknya Myrdal berhipotesis bahwa backwash effect akan lebih besar daripada trickledown effect karena proses cumulative causation (Rustiadi et al. 2009). Implikasi kebijakan dari hipotesis Perroux ini yaitu memperbanyak kutub pertumbuhan (polisentris) dan desentralisasi (Firman 2011; Priyarsono 2016). Namun beberapa penelitian justru mendukung hipotesis Myrdal bahwa ketimpangan pembangunan antarwilayah masih saja terjadi baik dalam lingkup nasional (Hadi 2011) maupun lingkup regional (Arifin 2009; Iswanto 2015). Isu sebenarnya dari penerapan model kutub pertumbuhan yaitu bagaimana dampak pusat pertumbuhan terhadap pertumbuhan ekonomi wilayah itu sendiri (Sharma 1984).

Tidak terbuktinya hipotesis Perroux mengindikasikan bahwa keterkaitan spasial antarwilayah tidak selalu bernilai positif dimana pertumbuhan ekonomi yang terjadi di kutub pertumbuhan akan mempengaruhi peningkatan pertumbuhan ekonomi di hinterland dan sebaliknya. Interaksi spasial yang terjadi dapat saja saling melemahkan satu wilayah dengan wilayah lainnya atau dapat saja pertumbuhan ekonomi terjadi secara asimetrik dimana hanya kutub pertumbuhan saja yang menikmati pertumbuhan ekonomi dengan menguras sumber daya di hinterland (Rustiadi et al. 2009). Sifat interaksi spasial ini dipengaruhi oleh berbagai faktor baik fisik maupun non fisik dengan mekanisme yang 
kompleks (Kenny \& Williams 2001), mengingat faktor-faktor pertumbuhan ekonomi dalam realitasnya dapat berpindah lokasi (mobile).

Salah satu provinsi dengan angka pertumbuhan ekonomi yang lebih besar dari pertumbuhan ekonomi nasional selama 2011-2014 yaitu Provinsi Jawa Timur berturutturut sebesar 6.50\%; 6.55\%; 6.31\%; 6.00\% (BPS 2016). Pertumbuhan ini tentunya diharapkan dapat dinikmati oleh seluruh wilayah kabupaten/kota dan seluruh lapisan penduduk di Provinsi Jawa Timur dengan strategi pembentukan 8 Wilayah Pengembangan (WP) melalui mekanisme spread effect dan polarization effect yang positif berdasarkan Peraturan Daeah Provinsi Jawa Timur No 5 Tahun 2012 tentang RTRW Provinsi Jawa Timur 2011-2031..

Perhitungan indeks gini (menunjukkan tingkat ketimpangan vertikal) di Provinsi Jawa Timur menunjukkan tren yang meningkat mulai tahun 2007-2015 berturut-turut yaitu $0.34 ; 0.33 ; 0.33 ; 0.34 ; 0.37 ; 0.36 ; 0.36 ; 0.37 ; 0.41$ (Kemendagri 2016), yang berarti ketimpangan vertikal di Provinsi Jawa Timur semakin melebar dari tahun 2007 ke tahun 2015. Ketimpangan horizontal antar kabupaten/kota di Provinsi Jawa Timur juga semakin melebar yang ditunjukkan oleh tren peningkatan indeks Williamson mulai tahun 2011-2014 berturut-turut yaitu 0.9415; 0.9451; 0.9467; 0.9532 (BPS 2016).

Meskipun terdapat keterkaitan spasial, ternyata fenomena pertumbuhan ekonomi wilayah yang tinggi disertai dengan ketimpangan vertikal dan ketimpangan horizontal yang tinggi dapat terjadi. Hal ini mengindikasikan bahwa keterkaitan spasial dapat bersifat negatif dan menarik untuk diteliti lebih lanjut. Tujuan umum penelitian ini yaitu mengeksplorasi pengaruh spasial pertumbuhan ekonomi wilayah secara agregat, dengan tujuan khusus penelitian yaitu mengidentifikasi eksistensi pengaruh spasial pertumbuhan ekonomi wilayah di Provinsi Jawa Timur dan mengkaji pengaruh spasial pertumbuhan ekonomi wilayah secara agregat antar kabupaten/kota di Provinsi Jawa Timur.

\section{METODE}

Data yang digunakan pada penelitian ini berupa data sekunder cross section 38 kabupaten/kota di Provinsi Jawa Timur yang bersumber dari BPS Jawa Timur. Mengingat terjadinya pertumbuhan ekonomi suatu wilayah membutuhkan waktu, data-data yang digunakan sebagai variabel bebas menggunakan data tahun 2010, sedangkan variabel terikat berupa data pertumbuhan PDRB perkapita tanpa migas dan/atau tanpa industri tembakau tiap kabupaten/kota menggunakan data tahun 2012-2015. Penggunaan 4 tahun yang berbeda pada variabel terikat bertujuan untuk melihat perbedaan pengaruh spasial pertumbuhan ekonomi wilayah tiap tahun, sehingga akan terdapat 4 model persamaan regresi. Secara detail variabel penelitian dapat dilihat pada Tabel 1.

Beberapa peneliti juga menggunakan PDRB riil per kapita sebagai proksi pertumbuhan ekonomi wilayah dan sebagai indikator untuk membandingkan pertumbuhan ekonomi antarwilayah (SAC et al. 2005; Harris 2008; Capello \& Nijkamp 2011; Veneri \& Ruiz 2013; Upreti 2015). PDB/PDRB riil per kapita dapat menunjukkan rata-rata standar hidup penduduk di suatu wilayah, dengan membagi total PDRB riil dengan jumlah penduduk di wilayah tersebut. Oleh karena itu dalam konteks penelitian cross-section, seorang peneliti akan lebih fokus pada perbandingan standar hidup penduduk antarwilayah daripada total produksi barang/jasa di wilayah tersebut (Blanchard 2007). Selain itu, PDB/PDRB riil per kapita merupakan ukuran pendapatan penduduk yang diasumsikan dapat mengalir ke wilayah yang lainnya (SAC et al. 2005), sehingga dalam konteks penelitian spasial, penggunaan proksi PDB/PDRB riil per kapita lebih sesuai dengan proses interaksi spasial. 
Tabel 1. Organisasi Variabel

\begin{tabular}{|c|c|c|}
\hline Aspek & Variabel & Definisi Operasional \\
\hline $\begin{array}{l}\text { Pertumbuhan } \\
\text { wilayah }\end{array}$ & $\begin{array}{l}\text { Perubahan PDRB } \\
\text { kabupaten/kota per kapita } \\
\text { (PDRB) }\end{array}$ & $\begin{array}{l}\text { Persentase perubahan PDRB ADHK tanpa migas } \\
\text { dan/atau tembakau per kapita kabupaten/kota dari akhir } \\
\text { tahun } 2010+n-1 \text { ke akhir tahun } 2010+n\end{array}$ \\
\hline Konsumsi & $\begin{array}{l}\text { Tingkat konsumsi penduduk } \\
\text { (KONS) }\end{array}$ & $\begin{array}{l}\text { Persentase penduduk dengan golongan pengeluaran } \\
\text { rata-rata sebulan }>500 \text { ribu rupiah di kabupaten/kota ke- } \\
\text { i pada tahun } 2010\end{array}$ \\
\hline Investasi & $\begin{array}{l}\text { Persentase alokasi belanja } \\
\text { modal pemerintah daerah } \\
\text { (INVES) }\end{array}$ & $\begin{array}{l}\text { Persentase alokasi belanja modal pemerintah pada APBD } \\
\text { kabupaten/kota ke-i pada tahun } 2010\end{array}$ \\
\hline \multirow{2}{*}{$\begin{array}{l}\text { Modal } \\
\text { manusia }\end{array}$} & $\begin{array}{l}\text { Persentase populasi penduduk } \\
\text { yang berpendidikan terakhir } \\
\text { SMP/sederajat (PDDK) }\end{array}$ & \multirow{2}{*}{$\begin{array}{l}\text { Persentase jumlah penduduk yang berpendidikan } \\
\text { terakhir SMP/sederajat di kabupaten/kota ke-i pada } \\
\text { tahun } 2010 \\
\text { Persentase jumlah penduduk yang menganggur } \\
\text { terhadap jumlah angkatan kerja di kabupaten/kota ke-i } \\
\text { pada tahun } 2010\end{array}$} \\
\hline & $\begin{array}{l}\text { Tingkat pengangguran terbuka } \\
\text { (TPT) }\end{array}$ & \\
\hline \multirow{2}{*}{$\begin{array}{l}\text { Spesialisasi } \\
\text { sektoral }\end{array}$} & $\begin{array}{l}\text { Tingkat spesialisasi } \\
\text { kabupaten/kota (SPES) }\end{array}$ & $\begin{array}{l}\text { Persentase tingkat spesialisasi kabupaten/kota ke-i } \\
\text { terhadap Provinsi Jawa Timur pada tahun } 2010 \text { yang } \\
\text { dihitung menggunakan rumus Indeks Spesialisasi } \\
\text { Krugman }\end{array}$ \\
\hline & Share sektor industri (INDUS) & $\begin{array}{l}\text { Persentase share PDRB sektor industri tanpa migas } \\
\text { dan/atau tembakau terhadap PDRB ADHK total di } \\
\text { kabupaten/kota ke-i pada tahun } 2010\end{array}$ \\
\hline
\end{tabular}

Sumber: Penulis, 2017

Seluruh variabel tersebut akan dimodelkan dengan regresi spasial untuk menangkap fenomena growth spillover. Salah satu bentuk model regresi spasial atau spatial autoregressive (SAR) yaitu spatial lag model (SLM). Bentuk SLM merupakan pengembangan dari general spatial model (GSM) dengan bentuk model sebagai berikut (Lesage 1999):

$$
\begin{aligned}
& Y_{i}=\rho W Y_{j}+X_{i} \beta+u_{s} \\
& u=\lambda W u_{j}+\varepsilon_{j}^{-} \\
& \epsilon \sim N\left(0, \sigma^{2}\right)
\end{aligned}
$$

jika $\rho \neq 0$ dan $\lambda=0$ maka persamaan GSM menjadi persamaan SLM sebagai berikut:

$$
\mathrm{Y}_{\mathrm{i}}=\rho W Y_{\mathrm{j}}+\mathrm{X}_{\mathrm{i}} \beta+\varepsilon_{\mathrm{i}}:
$$

dimana $Y_{i}$ merupakan variabel terikat di wilayah $\mathrm{i}, \mathrm{X}_{\mathrm{i}}$ merupakan matriks variabel bebas di wilayah i. W merupakan matriks pembobot spasial. $\rho$ merupakan koefisien lag spasial pada variabel terikat yang dapat diintepretasikan bahwa variabel terikat $\mathrm{Y}$ di wilayah $\mathrm{i}$ dipengaruhi secara spasial oleh variabel $\mathrm{Y}$ di wilayah $\mathrm{j}$ dan $\lambda$ merupakan koefisien lag spasial pada residual. Dalam konteks penelitian ini, spesifikasi model regresi linear yang akan disusun menjadi sebagai berikut:

$$
\begin{aligned}
\operatorname{PDRB}_{\mathrm{i} 2010+\mathrm{n}}= & \propto+\rho \mathrm{WW}_{\mathrm{ij}} \mathrm{PDRB}_{\mathrm{j} 2010+\mathrm{n}}+\beta_{1} \mathrm{KONS}_{\mathrm{i} 2010}+\beta_{2} \mathrm{INVES}_{\mathrm{i} 2010}+ \\
& \beta_{3} \text { PNDDK }_{\mathrm{i} 2010}+\beta_{4} \mathrm{TPT}_{\mathrm{i} 2010}+\beta_{5} \mathrm{SPES}_{\mathrm{i} 2010}+ \\
& \beta_{6} \operatorname{INDUS}_{\mathrm{i} 2010}+\varepsilon_{\mathrm{i} 2010}
\end{aligned}
$$

Elemen terpenting dari regresi spasial yang membedakannya dengan regresi linear global adalah matriks pembobot spasial. Matriks pembobot spasial merupakan matriks 
simetri berukuran $\mathrm{N}$ x $\mathrm{N}$ dengan elemen diagonalnya bernilai 0 . Matriks pembobot spasial yang digunakan pada penelitian ini yaitu matriks rook contiguity yang berdasarkan pendekatan kontiguitas dan matriks inverse euclidian distance squared yang berdasarkan pendekatan jarak.

1. Rook Contiguity, mendefinisikan wilayah tetangga (j) sebagai wilayah yang bersinggungan sisi $\left(\mathrm{l}_{\mathrm{ij}}\right)$ dengan wilayah asal (i), maka bobot spasial dapat dituliskan sebagai berikut:

$$
W_{i j}= \begin{cases}1, & l_{i j}>0 \\ 0, & l_{i j}=0\end{cases}
$$

2. Inverse Euclidian Distance Squared, mendefinisikan wilayah tetangga (j) adalah seluruh wilayah selain wilayah asal (i), namun wilayah tetangga (j) memiliki bobot yang semakin menurun seiring bertambahnya jarak Euclidian $\left(\mathrm{d}_{\mathrm{ij}}\right)$ dari wilayah asal (i), maka bobot spasial dapat dituliskan sebagai berikut:

$$
\mathrm{W}_{\mathrm{ij}}=\mathrm{d}_{\mathrm{ij}}^{-2}
$$

Prosedur pendugaan parameter pada regresi spasial diawali dengan penyusunan model regresi linear global (OLS) dan pengujian asumsi klasik yaitu identik, independen, dan distribusi normal menggunakan software Minitab 17, kemudian dilakukan uji asumsi spatial dependence dengan uji Lagrange Multiplier lag (Anselin 2003; Suharto 2011) menggunakan software R versi 3.3.2. Jika terbukti signifikan terdapat spatial dependence pada variabel terikat, maka dapat disusun spatial lag model menggunakan software R versi 3.3.2. Kemudian dilakukan uji kebaikan model terhadap model spasial apakah signifikan berbeda dengan model regesi linear global dengan uji LR, uji Wald dan AIC.

\section{HASIL DAN PEMBAHASAN}

Hasil analisis regresi linear global pada masing-masing model menunjukkan variasi pada variabel yang signifikan. Pada model I, variabel yang signifikan mempengaruhi pertumbuhan ekonomi yaitu variabel pendidikan dan variabel tingkat spesialisasi. Pada model II, variabel yang signifikan mempengaruhi pertumbuhan ekonomi yaitu variabel konsumsi, variabel pendidikan dan variabel tingkat spesialisasi. Pada model III, variabel yang signifikan mempengaruhi pertumbuhan ekonomi yaitu hanya variabel pendidikan. Pada model IV, variabel yang signifikan mempengaruhi pertumbuhan ekonomi yaitu variabel pendidikan dan variabel share industri. Pada keempat model tersebut hanya variabel pendidikan yang konsisten signifikan mempengaruhi pertumbuhan ekonomi tiap tahun.

Nilai $\mathrm{R}^{2}$ menunjukkan besarnya variansi kejadian pertumbuhan PDRB perkapita tanpa migas dan/tanpa tembakau di kabupaten/kota Jawa Timur yang dapat dijelaskan oleh variabel bebas. Nilai $\mathrm{R}^{2}$ terbesar terdapat pada model IV sebesar $40,76 \%$, sedangkan nilai $\mathrm{R}^{2}$ terkecil terdapat pada model III hanya sebesar $24.79 \%$. Hasil uji asumsi residual menunjukkan bahwa residual seluruh model mempunyai ragam yang homogen dan belum dapat ditentukan apakah residual menyebar secara independen atau tidak, kecuali model I dengan nilai DW = 1.889 yang menunjukkan bahwa residual menyebar secara independen. Berdasarkan nilai VIF setiap parameter yang kurang dari 10 menunjukkan bahwa tidak terjadi multikolinearitas. Hasil secara detail dapat dilihat pada Tabel 2 berikut.

Langkah berikutnya yaitu melakukan uji asumsi spatial dependence dengan uji Lagrange Multiplier (LM) lag. Jika asumsi spatial dependence terbukti signifikan, maka pendugaan paramater koefisien regresi linear dengan OLS masih tetap tidak bias, masih konsisten, mempunyai standard error yang bias ke bawah (underestimate) sehingga nilai statistik uji t tinggi (overestimate), penduga OLS tidak efisien lagi atau ragamnya tidak lagi minimum (Juanda 2009; Pertiwi et al.2012). 
Tabel 2. Pendugaan Paramaeter Koefisien Dengan Metode Regresi Linear Global (OLS)

\begin{tabular}{|c|c|c|c|c|}
\hline Parameter & $\begin{array}{c}\text { Estimasi Model I } \\
\left(\mathrm{Y}_{2012} . \mathrm{X}_{2010}\right)\end{array}$ & $\begin{array}{c}\text { Estimasi Model II } \\
\left(\mathrm{Y}_{2013} . \mathrm{X}_{2010}\right)\end{array}$ & $\begin{array}{c}\text { Estimasi Model III } \\
\left(\mathrm{Y}_{2014} . \mathrm{X}_{2010}\right)\end{array}$ & $\begin{array}{c}\text { Estimasi Model IV } \\
\left(Y_{2015} . \mathrm{X}_{2010}\right)\end{array}$ \\
\hline Intersep $(\alpha)$ & $0.0324^{\star \star \star}$ & $0.0362^{\star \star \star}$ & $0.03389^{\star \star \star}$ & $0,03248^{\star \star \star}$ \\
\hline KONS & 0.0048 & $0.02 *$ & 0.0038 & 0,00544 \\
\hline INVES & 0.0128 & -0.013 & 0.0136 & 0,0055 \\
\hline PNDDK & $0.081^{\star \star *}$ & $0.0492^{*}$ & $0.0615^{\star \star \star}$ & $0,0669 * \star \star$ \\
\hline TPT & -0.0536 & -0.0465 & -0.0111 & $-0,0105$ \\
\hline SPES & $0.0311^{*}$ & $0.0351^{* *}$ & -0.003 & 0,0087 \\
\hline INDUS & 0.0048 & -0.00022 & 0.00694 & $-0,0107$ * \\
\hline $\mathrm{R}^{2}$ & $25.46 \%$ & $30.52 \%$ & $24.79 \%$ & $40.76 \%$ \\
\hline Adj $R^{2}$ & $11.25 \%$ & $17.07 \%$ & $10.24 \%$ & $29.3 \%$ \\
\hline Nilai DW & 1.889 & 1.342 & 1.516 & 1.235 \\
\hline$P$-value uji Ragam & 0.297 & 0.728 & 0.32 & 0.106 \\
\hline$P$-value uji normalitas & 0.097 & 0.15 & 0.072 & 0.15 \\
\hline
\end{tabular}

Sumber: Hasil Analisis, 2017

Pada uji LM lag digunakan 2 jenis matriks pembobot spasial yaitu rook contiguity dan inverse euclidian distance squared. Hasil p-value uji LM lag pada Tabel 3 menunjukkan bahwa terdapat perbedaan pada penggunaan kedua jenis matriks pembobot spasial. Secara umum, dengan menggunakan matriks inverse euclidian distance squared, $p$ value LM lag signifikan pada taraf signifikansi $10 \%$ yang artinya terdapat spatial dependence antara variabel terikat antarwilayah, kecuali pada model I, $p$-value LM lag tidak signifikan, hasil ini konsisten dengan uji independen residual dengan Durbin-Watson sebelumnya. Hal ini diduga karena pengaruh spasial antarwilayah tidak terjadi dalam waktu yang singkat, namun merupakan akumulasi dari waktu ke waktu sehingga pengaruhnya dapat dirasakan pada waktu $\mathrm{t}+3$ tahun. $P$-value LM lag dengan menggunakan matriks rook contiguity pada seluruh model tidak ada yang signifikan pada taraf signifikansi $10 \%$.

Tabel 3. Hasil P-value Uji LM Lag

\begin{tabular}{llrrrr}
\hline No & $\begin{array}{l}\text { Jenis matriks pembobot } \\
\text { spasial }\end{array}$ & \multicolumn{1}{c}{ Model I } & \multicolumn{1}{c}{ Model II } & \multicolumn{1}{c}{ Model III } & \multicolumn{1}{c}{ Model IV } \\
\hline 1 & Rook contiguity & 0.5065 & 0,7030 & 0.1079 & 0.1157 \\
2 & $\begin{array}{l}\text { Inverse Euclidian } \\
\text { Distance Squared }\end{array}$ & 0.2454 & 0,0162 & 0.0092 & 0.0049 \\
\hline
\end{tabular}

Sumber: Hasil Analisis, 2017

Penelitian Veneri \& Ruiz (2013) yang menunjukkan bahwa spillover pertumbuhan ekonomi berkaitan dengan jarak antarwilayah, spillover magnitude ini akan berkurang seiring dengan bertambahnya jarak kedua wilayah. Sementara itu penelitian Puspitasari et al. (2011) menunjukkan bahwa tidak terdapat aspek spatial dependence pada kejadian pengurangan tingkat kemiskinan di suatu kabupaten/kota di Provinsi Jawa Timur dengan menggunakan rook contiguity. Hasil uji LM lag pada penelitian ini konsisten dengan hasil kedua penelitian sebelumnya.

Meskipun menggunakan matriks kontiguitas, penelitian yang dilakukan oleh Wardhana et al. (2015) tentang pengaruh spasial keberadaan agro-cluster terhadap pengurangan tingkat kemiskinan di Provinsi Jawa Barat menunjukkan adanya spatial dependence antarkelurahan. Perbedaan hasil antara penelitian Wardhana et al. (2015) dengan penelitian ini dan penelitian lain sebelumnya yaitu pada penggunaan unit analisis. 
Diduga hal ini berkaitan dengan sifat keterkaitan spasial pada variabel pertumbuhan ekonomi.

Pada unit analisis dengan lingkup lebih kecil, frekuensi interaksi spasial yang terjadi cenderung lebih tinggi dan cenderung mengelompok pada wilayah yang berbatasan langsung sehingga fenomena spatial dependence dapat ditangkap dengan matriks kontiguitas, yang mendefinisikan wilayah tetangga adalah wilayah yang berbatasan langsung dengan wilayah asal. Pada unit analisis dengan lingkup lebih luas, frekuensi interaksi spasial yang terjadi cenderung bergantung pada jarak antarwilayah dan interaksinya cenderung menyebar sehingga fenomena keterkaitan spasial dapat ditangkap dengan matriks jarak.

Pada hakikatnya, sebuah wilayah merupakan satu kesatuan yang tidak terpisahkan (satu entitas) (Maneepong 2012), sehingga antara satu kabupaten/kota dalam lingkup wilayah Provinsi Jawa Timur merupakan satu kesatuan. Hal ini dapat dilihat dari sudut pandang wilayah fungsional, dimana eksistensi keterkaitan antarkomponen atau keterkaitan antar kabupaten/kota ini memang diakui. Keterkaitan ini terjadi dikarenakan adanya efek komplementaritas antar kabupaten/kota (Rustiadi et al. 2009). Mengingat karakteristik spasial setiap kabupaten/kota tidak sama atau heterogen, maka muncul supply dan demand dari setiap kabupaten/kota yang saling berkomplementer dan mengakibatkan terjadinya keterkaitan antar kabupaten/kota.

Terdapat berbagai macam keterkaitan antar kabupaten/kota dimana setiap kabupaten/kota saling berinteraksi satu dengan lainnya. Interaksi ini pada gilirannya menghasilkan impuls yang bekerja dengan mekanisme yang kompleks dalam sistem perekonomian wilayah (Bendavid-Val 1991). Bendavid-Val (1991) mengklasifikasikan keterkaitan antar kabupaten/kota menjadi 7 macam yaitu keterkaitan transportasi, keterkaitan komunikasi, keterkaitan sumber daya alam, keterkaitan ekonomi, keterkaitan sosial, keterkaitan pelayanan umum dan keterkaitan institusi. Preston mengklasifikasikan bentuk-bentuk keterkaitan yang mungkin terjadi antara lain aliran orang dan migrasi, aliran barang, aliran jasa, aliran energi, aliran finansial, aliran aset serta aliran informasi, sedangkan Rondinelli membagi keterkaitan menjadi 7 macam yaitu keterkaitan fisik, keterkaitan ekonomi, keterkaitan pergerakan penduduk, keterkaitan teknologi, keterkaitan interaksi sosial, keterkaitan pelayanan, keterkaitan politik (Rustiadi et al. 2009). Douglas (1998) mengklasifikasikan keterkaitan antar kabupaten/kota menjadi 5 macam yaitu keterkaitan penduduk, keterkaitan produksi, keterkaitan komoditas, keterkaitan modal dan keterkaitan informasi. Menurut Berdegue et al. (2015), pertumbuhan sebuah wilayah dapat mempengaruhi wilayah lainnya melalui beberapa jalur yaitu human capital, konektivitas fisik dan virtual, diversitas sosial, diversifikasi produktif, investasi publik, aksesibilitas terhadap sektor jasa, dan kompetisi politik.

Berdasarkan hasil uji LM lag sebelumnya, model I tidak diregresikan dengan spatial lag model karena memang tidak terdapat spatial dependence. Hasil spatial lag model selainnya dengan menggunakan matriks inverse euclidian distance squared dapat dilihat selengkapnya pada Tabel 4 berikut. Uji LR dan uji Wald pada ketiga model signifikan pada taraf signifikansi $5 \%$, yang mengindikasikan bahwa terdapat perbedaan yang siginifkan antara model regresi linear global dengan SLM. Nilai AIC pada ketiga model lebih kecil daripada nilai AIC for $\mathrm{lm}$ yang mengindikasikan bahwa persamaan SLM lebih baik dibandingkan dengan persamaan regresi linear global.

Variabel yang signifikan pada model II yaitu variabel konsumsi, variabel pendidikan, variabel tingkat spesialisasi sektoral, variabel spatial lag. Pada model III, variabel investasi menjadi signifikan pada taraf signifikansi $15 \%$ dan variabel share industri, sedangkan variabel konsumsi menjadi tidak signifikan. Pada model IV, hanya variabel pendidikan saja yang siginifikan. Dari ketiga model, hanya variabel pendidikan yang konsistem signifikan mempengaruhi pertumbuhan ekonomi wilayah di Provinsi Jawa Timur. 
Tabel 4. Pendugaan Paramaeter dengan Metode Spatial Lag Mode/(SLM)

\begin{tabular}{lrrr}
\hline Parameter & Estimasi Model II & Estimasi Model III & Estimasi Model IV \\
\hline Intersep $(\alpha)$ & $0.02759^{\star \star \star}$ & $0.02384^{\star \star \star}$ & $0.02522^{\star \star \star}$ \\
Variabel spatial lag $(\rho)$ & $-0.17355^{\star \star \star}$ & $-0.21063^{\star \star \star}$ & $-0.16317^{\star \star \star}$ \\
KONS & $0.01782^{\star \star}$ & 0.00242 & 0.00435 \\
INVES & 0.00387 & $0.03109^{\star}$ & 0.01863 \\
PNDDK & $0.09435^{\star \star \star}$ & $0.10998^{\star \star \star}$ & $0.10387^{\star \star \star}$ \\
TPT & -0.02114 & 0.01788 & 0.00721 \\
SPES & $0.03980^{\star \star \star}$ & 0.01065 & 0.01338 \\
INDUS & 0.00422 & $0.01233^{\star \star}$ & -0.00646 \\
\hline$P$-value uji LR & 0.008 & 0.00169 & 0.000953 \\
$P$-value uji Wald & 0.005 & 0.00039 & 0.000235 \\
AIC & -269.9 & -283 & -307.91 \\
AIC for lm & -264.9 & -275.15 & -299 \\
\hline Ket: $\left.{ }^{* \star}\right)$ signifikan pada taraf signifikansi $5 \% ; * \star$ & signifikan pada taraf signifikansi $10 \%, *)$ signifikan pada taraf \\
signifikansi $15 \%$ & & &
\end{tabular}

Sumber: Hasil Analisis, 2017

Berdasarkan hasil ini, dapat diduga bahwa pengaruh variabel konsumsi terhadap pertumbuhan ekonomi wilayah di Provinsi Jawa Timur hanya dalam jangka pendek. Menurut teori endogenous growth yang digagas oleh Romer (Todaro \& Smith 2006), kondisi ini mengindikasikan bahwa konsumsi penduduk di Provinsi Jawa Tmur sebagain besar dibelanjakan hanya pada barang-barang konsumsi habis pakai yang tidak berdampak panjang pada akumulasi modal, yang .pada gilirannya akumulasi modal ini dapat meningkatkan produksi barang/jasa di Provinsi Jawa Timur.

Menurut pendapat Marshal-Arrow-Romer (MAR) yang memandang bahwa spesialisasi sebuah wilayah merupakan prasyarat pertumbuhan wilayah, dimana akan terjadi aglomerasi hingga muncul keuntungan-keuntungan aglomerasi yang mempengaruhi pertumbuhan wilayah secara positif (Landiyanto 2005). Berdasarkan Tabel 4 diatas, keuntungan dari spesialisasi sektoral ini dapat diduga hanya mempengaruhi pertumbuhan ekonomi wilayah dalam jangka pendek. Hal ini dapat disebabkan oleh kurang sinergisnya keterkaitan antara wilayah yang terspesialisasi dengan wilayah selainnya. Selain itu dari 38 kabupaten/kota di Provinsi Jawa Timur, hanya 4 kabupaten/kota yang memiliki tingkat spesialisasi tertinggi pada sektor industri pertambangan dan penggalian yang memiliki sectoral linkage, knowledge spillover terbatas terhadap wilayah selainnya yang tidak memiliki sumberdaya pertambangan dan penggalian sebagai produksi utama.

Variabel investasi dan variabel share industri signifikansi pada model III mengindikasikan bahwa pengaruh kedua variabel tersebut membutuhkan waktu minimal 4 tahun setelah kegiatan investasi dilakukan, begitu juga dengan share industri terhadap pertumbuhan ekonomi wilayah. Namun pada model IV, kedua variabel ini tidak signifikan mempengaruhi pertumbuhan ekonomi di Provinsi Jawa Timur. Hal ini dapat diduga bahwa anggaran belanja pemerintah daerah tidak banyak dibelanjakan pada jenis investasi yang berjangka panjang, misalnya infrastruktur jalan, jembatan, dan prasarana lainnya, melainkan banyak dibelanjakan pada perbaikan/pembangunan gedung pemerintahan yang memberikan multiplier pertumbuhan yang tidak terlalu besar. Beberapa dugaan mengenai share industri yang hanya signifikan pada model III dapat mengindikasikan beberapa hal, bahwa pertumbuhan ekonomi di Provinsi Jawa Timur tidak digerakkan oleh sektor industri, mengingat kawasan industri terpusat di Kota Surabaya dan sekitarnya saja; multiplier share industri terbesar yang dihasilkan oleh kawasan industri tidak banyak menggerakkan pertumbuhan ekonomi di Provinsi Jawa Timur, melainkan terdapat kebocoran wilayah; kaitan kedepan dan kaitan kebelakang sektoral di Provinsi Jawa Timur tidak berjalan sinergis. Menurut Rustiadi et al. (2009), wilayah yang berkembang ditunjukkan oleh adanya keterkaitan antara sektor ekonomi wilayah yang sinergis. 
Hal yang menarik dari hasil analisis SLM diatas yaitu variabel pendidikan yang konsisten signifikan pada ketiga model. Variabel pendidikan diproksi dengan data persentase jumlah penduduk yang memiliki pendidikan terakhir SMP/sederajat. Hasil ini mengindikasikan bahwa perekonomian di Provinsi Jawa Timur masih digerakkan oleh tenaga kerja dengan pendidikan rendah. Koefisien variabel tersebut mengalami peningkatan dari model II ke model III sebesar 0.0156, lalu turun kembali pada model IV sebesar 0.0061, hal ini dapat diduga bahwa produktivitas penduduk dengan pendidikan terakhir SMP/ sederajat mengalami peningkatan dari model II ke model III, kemudian mengalami sedikit penurunan produktivitas pada model IV. Peningkatan produktivitas ini juga mengindikasikan bahwa human capital mengalami increasing return to scale dan jika penduduk memiliki pendidikan terakhir lebih tinggi dari SMP/sederajat diduga koefisien pada model IV akan meningkat.

Perbedaan antara model regresi OLS dengan SLM yaitu terdapatnya variabel lag spasial $(\rho)$ pada SLM. Variabel ini menunjukkan bahwa pertumbuhan ekonomi di suatu kabupaten/kota dapat mempengaruhi pertumbuhan ekonomi di kabupaten/kota lain dan juga dapat dipengaruhi oleh pertumbuhan ekonomi di kabupaten/kota lain di Provinsi Jawa Timur. Berdasarkan hasil analisis pada Tabel 4 diatas, koefisien lag spasial bernilai negatif yang menunjukkan bahwa pengaruh pertumbuhan ekonomi di sebuah wilayah berpengaruh negatif terhadap pertumbuhan ekonomi di wilayah tetangganya (negative growth spillover) atau saling melemahkan. Hasil ini sesuai dengan dugaan di awal bahwa pengaruh pertumbuhan ekonomi sebuah wilayah tidak selalu bernilai positif terhadap pertumbuhan ekonomi di wilayah lainnya. Dampak backwash effect dalam kegiatan pembangunan yang dilaksanakan oleh masing-masing wilayah saat ini lebih besar dibandingkan dengan spread effect yang dihipotesiskan oleh Perroux melalui teori kutub pertumbuhan.

Menurut Rustiadi et al. (2009), faktor-faktor yang menyebabkan terjadinya polarization effect/backwash effect sebagai akibat interaksi antar kabupaten/kota yang negatif yaitu perpindahan tenaga kerja dari wilayah yang terbelakang ke wilayah yang lebih maju, arus investasi yang tidak seimbang, pola dan aktivitas perdagangan didominasi oleh industri-industri di wilayah yang lebih maju, dan tersedianya aksesibilitas yang lebih baik di wilayah yang lebih maju. Fenomena backwash pada wilayah yang terbelakang berlangsung melalui beberapa tahap aliran yaitu oleh (1) aliran sumber daya alam, (2) aliran sumber daya manusia berkualitas, (3) aliran sumber daya finansial, (4) aliran sumber daya informasi dan (5) aliran kekuasaan.

Nilai koefisien lag spasial semakin negatif pada model III dibandingkan pada model II yang menunjukkan bahwa negative growth spillover magnitude antarwilayah semakin besar seiring bertambahnya waktu. Namun pada model IV, negative spillover magnitude ini berkurang bahkan nilainya lebih besar dibandingkan dengan koefisien pada model II. Berdasarkan variasi nilai koefisen lag spasial ini dapat diindikasikan bahwa spillover magnitude dari waktu ke waktu dapat mengalami perubahan. Perubahan magnitude ini diduga dipengaruhi oleh banyak faktor dengan mekanisme yang kompleks (Kenny \& Williams 2001), mengingat jenis keterkaitan antarwilayah sangat beragam yang secara agregat bersama-sama menghasilkan pertumbuhan ekonomi wilayah dan kemudian mempengaruhi pertumbuhan ekonomi wilayah lainnya. Terdapat juga kemungkinan bahwa faktor-faktor pertumbuhan ekonomi di suatu kabupaten/kota mempengaruhi pertumbuhan ekonomi di kabupaten/kota tersebut dan di saat yang bersamaan mempengaruhi pertumbuhan ekonomi di kabupaten/kota lainnya mengingat faktor-faktor pertumbuhan bersifat mobile.

Pengaruh spasial yang ditunjukkan oleh koefisien lag pada penelitian bersifat tidak langsung (indirect) yang artinya bahwa faktor-faktor pertumbuhan ekonomi di suatu wilayah kabupaten/kota tidak secara langsung mempengaruhi pertumbuhan ekonomi 
wilayah kabupaten/kota lainnya. Faktor-faktor pertumbuhan ekonomi di wilayah kabupaten/kota tersebut mempengaruhi secara langsung pertumbuhan ekonomi wilayah kabupaten/kota itu sendiri terlebih dahulu, dan kemudian pertumbuhan ekonomi wilayah kabupaten/kota tersebut pada gilirannya mempengaruhi pertumbuhan ekonomi wilayah selainnya.

Mengingat wilayah Provinsi Jawa Timur sebagai satu kesatuan fungsional atau satu entitas, maka kebijakan pembangunan masing-masing kabupaten/kota sebagai subwilayah akan saling mempengaruhi satu sama lain. Oleh karena itu adanya kolaborasi pembangunan antar kabupaten/kota di Provinsi Jawa Timur mutlak diperlukan dalam rangka mencegah dampak negatif dari pertumbuhan ekonomi yang tidak diinginkan dan menjaga keberlanjutan pembangunan dalam jangka panjang (Maneepong 2012).

\section{KESIMPULAN}

Eksistensi pengaruh spasial pertumbuhan ekonomi wilayah di Provinsi Jawa Timur terbukti pada model II, model III dan model IV. Koefisien lag pada ketiga model bernilai negatif yang menunjukkan terjadi fenomena negative growth spillover dimana pembangunan yang dilaksanakan suatu kabupaten/kota berpengaruh negatif terhadap pembangunan di kabupaten/kota lainnya serta memiliki magnitude yang bervariasi setiap tahun. Negative growth spillover ini juga mengindikasikan bahwa proses pembangunan di masing-masing kabupaten/kota di Provinsi Jawa Timur cenderung bersifat tidak saling sinergis dan tidak saling menguatkan satu dengan lain, sehingga akibat yang ditimbulkan yaitu ketimpangan pertumbuhan ekonomi wilayah.

Meskipun penelitian ini dapat menunjukkan eksistensi growth spillover secara spasial, namun dalam realitasnya growth spillover tidak terjadi sekaligus dalam satu waktu. Untuk menangkap fenomena ini lebih baik, penelitian selanjutnya dapat menggunakan data panel dimana tidak hanya terdapat spatial lag namun juga time lag. Selain itu kemungkinan faktor-faktor pertumbuhan ekonomi di suatu wilayah mempengaruhi secara langsung pertumbuhan ekonomi wilayah lainnya perlu dieksplorasi lebih lanjut. Hasil penelitian ini dapat dijadikan dasar untuk mengevaluasi proses pembangunan yang terjadi di seluruh kabupaten/kota di Provinsi Jawa Timur dan merumuskan strategi pembangunan wilayah yang sinergis.

\section{DAFTAR PUSTAKA}

Adisasmita R. 2008. Pengembangan Wilayah: Konsep dan Teori. Yogyakarta (ID): Graha Ilmu

Anselin L. 2003. Spatial Econometric. Baltagi BH, editor. A Companion to Theoritical Econometrics. Blackwell Publishing Ltd. hlm 310-330

Arifin Z. 2009. Kesenjangan dan Konvergensi Ekonomi Antar Kabupaten Pada Empat Koridor di Provinsi Jawa Timur. Humanity. 4(2): 154-164

Arman, Hadi S, Fauzi A, Achsani NA. 2017. Assessing the Effect of Inter-Regional Spillover and Feedback in Indonesia. International Journal of Environmental Problems. 3(1): 13-25

Bendavid-Val A. 1991. Regional and Local Economic Analysis for Practitioners. Ed ke-4. Westport (US): Praeger Publishers

Berdegue JA, Carriazo F, Jara B, Modrego F, Soloaga I. 2015. Cities, Territories, and Inclusive Growth: Unraveling Urban-Rural Linkages in Chile, Colombia, and Mexico. World Development. 73:56-71

Blanchard O. 2007. Macroeconomics. Ed ke-5. Boston (US): Pearson Education Inc.

[BPS] Badan Pusat Statistik. 2016. Produk Domestik Regional Bruto Jawa Timur 2010-2014. Surabaya (ID): BPS

Capello R. 2011. Location, Regional Growth and Local Development Theories. AESTIMUM. 58:1-25

Capello R, Nijkamp P. 2011. Regional Growth and Development Theories Revisited (Chapter 15) di dalam Endogeneous Regional Development: Perspectives, Measurement and Empirical Investigation. Stimson R, Stough RR, Nijkamp P, editor. Edward Elgar Publishing Inc. 
Cheshire PC, Malecki EJ. 2004. Growth, Development, and Innovation: A Look Backward and Forward. Papers in Regional Science. 83:249-267

Douglas M. 1998. A Regional Network Strategy for Reciprocal Rural-Urban Lingkages: An Agenda for Policy Research with Reference to Indonesia. Third World Planning Review. 20(1): 124-154

Firman T. 2011. Membangun Kelembagaan Kerjasama Antardaerah di Wilayah Metropolitan di Indonesia. Orasi Ilmiah Dies Natalis ITB ke-52. Bandung (ID)

Hadi S. 2001. Studi Dampak Kebijaksanaan Pembangunan Terhadap Disparitas Ekonomi Antar Wilayah (Pendekatan Model Analisis Sistem Neraca Sosial Ekonomi) [disertasi]. Bogor (ID): Institut Pertanian Bogor

Harris R. 2008. Discussion Paper: Models of Regional Growth: Past, Present and Future [Internet]. [diunduh 29 April 2017] Tersedia pada: http://www.spatialeconomics.ac.uk/textonly/SERC/publications/ download/sercdp0002.pdf

Iswanto D. 2015. Ketimpangan Pendapatan Antar Kabupaten/Kota dan Pertumbuhan Ekonomi di Propinsi Jawa Timur. Signifikan. 4(1): 41-66

Juanda, B. 2009. Metodologi Penelitian Ekonomi dan Bisnis. Ed ke-2. Bogor (ID): IPB Pr.

Junaidi, Rustiadi E, Sutomo S, Juanda B. 2012. Pengembangan Penyelenggaraan Transmigrasi di Era Otonomi Daerah: Kajian Khusus Interaksi Permukiman Transmigrasi dengan Desa Sekitarnya. Jurnal Visi Publik. 9(1): 522-534

Kenny C, Williams D. 2001. What Do We Know About Economic Growth? Or, Why Don't We Know Very Much? World Development. 29(1): 1-22

Landiyanto EA, 2005. Spesialisasi dan Konsentrasi Spasial Pada Sektor Industri Manufaktur di Jawa Timur. Dipresentasikan pada Academic Seminar: Indonesian Economy Under Global Change; 2005 Nov 16-17; Jakarta, Indonesia.

Lehtonen O, Wuori O, Muilu T. 2015. Comparing the Extend of the Spread Effect: Rural-Urban Commuting in Finnish Working Regions. Journal of Geographic Information System. 7: 29-42

Lesage JP. 1999. The Theory and Practice of Spatial Econometrics. Ohio (US): University of Toledo

Maggioni MA, Uberti TE, Nosvelli M. 2014. Does Intentional Mean Hierarchical? Knowledge Flows and Innovative Performance of Europeans Regions. Annals of Regional Science. 53(2): 453-485

Maneepong C. 2012. Rural-Urban and Intra-Urban Linkages in Southeast Asia: Old Field, New Dynamics (Chapter 8) di dalam Urbanization in Southeast Asia: Issues and Impacts. Sheng YK, Thuzar M, editor. Singapura: ISEAS Publishing

Pasaribu E, Priyarsono DS, Siregar H, Rustiadi E. 2015. Multipolarity Effect of Growth Centers Between Kalimantan and Other Major Islands in Indonesia: Can It Diminish Inter-Island Disparity? International Journal of Sciences: Basic and Applied Research. 24(2): 403-416

Pertiwi LD, Salamah M, Sutikno. 2012. Spatial Durbin Model untuk Mengidentifikasi Faktor-Faktor yang Mempengaruhi Kematian Ibu di Jawa Timur. Jurnal Sains dan Seni ITS. 1(1): 165-170

Pravitassari AE, Saizen I, Rustiadi E. 2016. Towards Resilience of Jabodetabek Megacity: Developing Local Sustainability Index with Considering Local Spatial Interdependency. International Journal Sustainable Future for Human Security. 4(1): 27-34

Pribadi DO, Putra AS, Rustiadi E. 2014. Determining Optimal Location of New Growth Centers Based On LGPIRIO Model to Reduce Regional Disparity in Indonesia. Ann Reg Sci. doi: 10.1007/s00168-014-0647-8

Priyarsono DS. 2016. Membangun Pinggiran: Tinjauan dari Perspektif Ilmu Ekonomi Regional. Journal of Regional and Rural Development Planning. 1(1): 42-52

Puspitasari M, Nurmalasari V, Sjafii A. 2009. Investigating Economic Growth Impact on Poverty Reduction in East Java: Does Spatial Matter? Di dalam: Priyarsono D, Rustiadi E, editor. Regional Development in Indonesia; 2009 Jul 15; Bogor, Indonesia. Bogor (ID): Crestpent Pr, hlm 49-72

Rustiadi E, Saefulhakim S, Panuju DR. 2009. Perencanaan dan Pengembangan Wilayah. Jakarta (ID): Crestpent Pr. dan Yayasan Pustaka Obor Indonesia

Rustiadi E, Nasution A. 2017. Can Social Capital Investment Reduce Poverty in Rural Indonesia? International Journal of Economics and Financial Issues. 7(2): 109-117

[SAC; AI; UOG] Scottish Agricultural College; Arkleton Institute; University of Gloucestershire. 2005. Final Report: Economic Linkages Between Small Towns And Surrounding Rural Areas in Scottland [Internet]. [diunduh 13 Juli 2017]. Tersedia pada: http://www.gov.scot/Publications/2005/03/20911/55370

Sharma PR. 1984. Growth Centre and Regional Development. Habitat Intl. 8(2):133-150

Steindl S, Tichy G. 2009. Cycles and Growth: An Introduction. Empirica. 36: 159-164 
Suharto E. 2011. Robust Lagrange Multiplier Pada Pemodelan Regresi Spasial Dependensi: Penyusunan Model Angka Kematian Bayi Di Provinsi Jawa Timur. [tesis]. Surabaya (ID): Institut Teknologi Sepuluh Nopember

Suparta IW. 2009. Spillover Effect Perekonomian Provinsi DKI Jakarta dan Sumatera Selatan Terhadap Pertumbuhan Ekonomi Provinsi Lampung. Jurnal Ekonomi Pembangunan. 10(1): 32-48

Todaro M, Smith SC. 2006. Pembangunan Ekonomi Jilid 1. Munandar H, Puji AL, penerjemah; Barnadi D, Saat S, Hardani W, editor. Jakarta (ID): Penerbit Erlangga. Terjemahan dari: Economic Development. Ed ke9.

Upreti P. 2015. Factors Affecting Economic Growth in Developing Countries. Major Themes in Economics. 17:37-54

Veneri P, Ruiz V. 2013. Urban to Rural Population Growth Linkages: Evidence from OECD TL3 Regions. OECD Regional Development Working Papers [Internet]. [diunduh 1 September 2015]. Tersedia pada: http://dx.doi.org/10.1787 /5k49lcrq88g7-en

Wardhana D, Ihle R, Heijman W. 2015. The Effect of Agro-clusters on Rural Poverty: A Spatial Perspective for West Java of Indonesia. Dipresentasikan pada 150th EAAE Seminar: The Spatial Dimension in Analysing the Linkages Between Agriculture, Rural Development and The Environment, 2015 Okt 22-23; Edinburgh, United Kingdom.

Wojnicka E. 2014. Growth Pole Theory As A Concept Based On Innovation Activity Development And Knowledge Diffusion. Uniwersytet Gdans 